\title{
O Brasil jagunço: retórica e poética
}

\author{
Willi Bolle *
}

\section{Resumo}

0 tema do banditismo no Brasil, depois de ter sido registrado por autores como Euclides da Cunha, Caio Prado Jr. e Oliveira Vianna, ganha no romance Grande sertão: veredas, de Guimarães Rosa, uma representação que corresponde à importância que esse fenômeno ocupa na vida cotidiana do país. Com a narração ficcional da guerra de jagunços, ou seja, bandos de criminosos disputando o poder no planalto central do país por volta de 1900, o romance fornece um retrato do Brasil que não se limita a acontecimentos do passado, mas evoca alegoricamente estruturas que se prolongam até os dias atuais. 0 conceito de "sistema jagunço", introduzido pelo autor, contribui para fazer do romance uma forma de pesquisa que se equipara aos melhores retratos sociológicos e historiográficos do Brasil; ele até os supera, pela lucidez e qualidade técnica da apresentação. 0 fato de o narrador ser ele próprio um jagunço, um "jagunço letrado”, não só proporciona uma visão de dentro do mundo do crime, como também expõe detalhadamente o funcionamento da instituição da jagunçagem através de uma encenação da retórica dos chefes e de seus subalternos. Por meio de uma poética astuciosa, crítica e auto-reflexiva, o romancista revela como a violência institucionalizada articula seu discurso.

\section{Palavras-chave}

Guimarães Rosa, retratos do Brasil, Brasil (ficção, história, política), banditismo, jagunçagem (sistema jagunço).

\footnotetext{
* professor no Departamento de Letras Modernas da FFLCH-USP.
} 
revista do ieb n 44 p. 141-158 fev 2007

\title{
Brazil jagunço: rhetoric and poetics
}

Willi Bolle

\begin{abstract}
After the works of authors like Euclides da Cunha, Caio Prado Jr. and Oliveira Vianna, banditism has won, in the novel Grande sertão: veredas, by Guimarães Rosa, a representation that matches its importance in Brazil's everyday life. With the ficcional narration of the jagunços'war (i.e., bands of criminals fighting for power in the central area of the country around 1900), the novel offers a portrait of Brazil which evokes structures that remain present nowadays. The concept of the "jagunço system", introduced by Guimarães Rosa, turns the novel into a form of research that overcomes the best sociological and historical portraits of Brazil. The fact that the narrator is himself a jagunço, a "literate jagunço", not only offers an inside view of the world of crime, but also exposes the mechanism of the jagunço institution by picturing the rhetoric between the bosses and their subordinates.
\end{abstract}

\section{Keywords}

Guimarães Rosa, portraits of Brazil, Brazil (ficction, history, politics), banditism, jagunçagem (jagunço system). 


\section{0 banditismo no Brasil: Estudos precursores}

0 banditismo, por enquanto, não consta dos manuais de História do Brasil. Dentre os principais retratos historiográficos e sociológicos do País, só alguns poucos, como os de Euclides da Cunha, Caio Prado Jr. e Oliveira Vianna, comentam o fenômeno. 0 autor de Os sertões (1902) fornece um esboço pioneiro. "A nossa civilização", observa ele a respeito do mecanismo das eleições no interior do país, "arregimentava [...] sempre [...] o banditismo sertanejo." 0 "saque de vilas e cidades" era elemento integrante das "campanhas eleitorais do Império", ou seja, o banditismo "fazia parte da disputa política oficial"2.

Essas observações de Euclides sobre o sertão são estendidas por Caio Prado Jr. ao país inteiro e aprofundadas em suas causas econômicas e sociais. Em Formação do Brasil contemporâneo (1942), é focalizada a parte da população constituída pelos "desocupados permanentes": "Vagando de léu em léu, à cata do que se manter", este contingente, "apresentando-se a ocasião, envereda francamente pelo crime." Segundo Caio Prado Jr., o banditismo neste país é "uma verdadeira endemia social": "É naquele elemento desenraizado da população brasileira que se recrutará a maior parte da força armada para a luta das facções políticas"3. Portanto, mais um testemunho de que, no Brasil, o crime é parte integrante das estruturas políticas.

Ao avaliar a relação entre poder e crime, os referidos autores divergem radicalmente. Euclides revolta-se com uma "justiça", que "parlamenta com os criminosos [...] e acaba ratificando [com eles] verdadeiros tratados de paz, sancionando a soberania da capangagem impune". Ele denuncia a conivência das autoridades públicas, em nível nacional, com "esse velho regime de desmandos”. Já Caio Prado Jr. apresenta uma espécie de justificativa, advogando a organização de bandos por chefes políticos em nome da "segurança" e da "tranquilidade". Sua argumentação é esta:

0 arrolamento dos indivíduos sem eira nem beira nas milícias particulares dos grandes proprietários e chefes locais ainda

1 CUNHA, Euclides da. Os sertões: campanha de Canudos. Edição crítica organizada por Walnice Nogueira Galvão. São Paulo: Ática, 1998. p. 167.

2 Ibid. p. 187-8.

3 PRADO Jr., Caio. Formação do Brasil contemporâneo. São Paulo: Martins, 1942. p. 280-1.

4 CUNHA, Euclides da. op.cit. p. 188-9. 
constitui um penhor de segurança e tranquilidade, porque canaliza sua natural turbulência e lhes dá um mínimo de organização e disciplina. ${ }^{5}$

Podemos completar o quadro com a posição mais neutra, mais descritiva de Oliveira Vianna. Em Instituições politicas brasileiras (1949), ele nos faz lembrar que o povoamento do Brasil começou com o direito expresso de "couto e homizio". 0 coiteiro, ou seja, o indivíduo que dá proteção aos criminosos, e o seu corolário, o capanga, são "tipos sociais que o período colonial elaborou" e que "florecem [até hoje], onde a autoridade do poder público é fraca ou ausente". 0 banditismo coletivo, notadamente a arregimentação de capangas pelos chefes políticos do sertão, é aqui uma instituição do direito público costumeiro ${ }^{6}$. Ou seja, há muito tempo que Crime e Lei dialogam e se entendem na sociedade brasileira.

\section{A representação do banditismo em Grande sertão: veredas}

No entanto, é somente com Grande sertão: veredas (1956) que o problema do crime ganha, nos retratos do Brasil, a dimensão complexa que tem na realidade. Guimarães Rosa narra uma história de bandos de jagunços que, por volta de 1900, organizam o crime e exercem o poder no planalto central do País. 0 conceito introduzido pelo seu narrador, o "sistema jagunço", contribui para fazer do romance uma forma de pesquisa, que se equipara aos melhores retratos sociológicos e historiográficos do Brasil e concorre com eles.

Com efeito, o "sistema jagunço" é uma grande metáfora para designar o complexo de violência e miséria, a história dos sofrimentos do povo, a falta de justiça e de diálogo social - em suma, "esse velho regime de desmandos" que bloqueia o processo democrático e a emancipação do país. Longe de narrar uma história de antigamente, o romancista, que "se lembra das coisas, antes delas acontecerem", desenhou visionariamente o quadro de uma sociedade - a nossa - que se criminaliza à medida que avança no caminho da modernização.

Com a encenação de bandos de criminosos atuando na região central do Brasil, Guimarães Rosa não retrata um poder

5 PRAD0 Jr., Caio. Formação do Brasil contemporâneo. São Paulo: Martins, 1942. p.282.

6 VIANNA, Oliveira. Instituições politicas brasileiras. Belo Horizonte: Itatiaia; São Paulo: EDUSP; Niterói: Editora da UFF, 1987. v.1, p. 149-160 (Coleção Reconquista do Brasil. 2. série. v. 105). 
paralelo, mas o poder. Grande sertão: veredas é um retrato alegórico do País. Representa não apenas a situação por volta de 1900, que corresponde ao tempo narrado. Em plena era desenvolvimentista, quando se inicia a construção da nova capital Brasília, o romancista focaliza a persistência das estruturas arcaicas sob a fachada moderna, uma situação que se perpetua até os dias atuais. Com tudo isso, o romance de Guimarães Rosa é o mais exato e mais lúcido retrato do Brasil.

Quanto à avaliação das relações entre poder e crime, ela não se resolve, para o autor de Grande sertão: veredas, numa manifestação pontual de repúdio, como em Euclides, nem de justificativa, como em Caio Prado Jr. ou de descrição neutra como em Oliveira Vianna. O problema é tratado pelo romancista de forma muito mais profunda. 0 sistema jagunço é apresentado por um personagem-narrador envolvido nesse universo de corpo e alma, com máxima intensidade existencial. Eis o que faz a diferença qualitativa de Grande sertão: veredas em comparação com os referidos retratos ensaísticos do Brasil. 0 problema da aliança entre poder e crime não se resume numa discussão temática ou ideológica, mas impregna a feitura formal do texto. 0 "mundo brutal do sertão" é apresentado "através da consciência [de um] dos próprios agentes da brutalidade"7. Ou seja, é a própria voz do crime que fala, a narração do jagunço Riobaldo proporciona ao leitor uma visão de dentro da jagunçagem.

Uma qualidade específica da apresentação rosiana do sistema jagunço, vale dizer, do sistema do poder, é que ela é feita através do prisma da linguagem, enquanto constelação de discursos. A perspectiva e a linguagem são de um jagunço letrado.

\section{0 jagunço letrado e sua genealogia}

Com o conceito de jagunço letrado, introduzido nos debates por Walnice Galvão ${ }^{8}$ (1972), retomo uma tarefa à qual me dediquei mais detalhadamente no meu livro grandesertão. br: o romance de formação do Brasil (2004): estudar o jagunço letrado para analisar através dessa perspectiva o próprio sistema jagunço ${ }^{9}$.

7 CANDIDO, Antonio. Jagunços mineiros de Claudio a Guimarães Rosa. In: . Vários escritos. São Paulo: Duas Cidades, 1970. p. 133-160.

8 GALVÃo, Walnice Nogueira. As formas do falso: um estudo sobre a ambigüidade em Grande Sertão: Veredas. São Paulo: Perspectiva, 1972.

9 BOLLE, Willi. Grandesertão.br: o romance de formação do Brasil. São Paulo: Duas Cidades; Ed. 34, 2004. 
0 romance de Guimarães Rosa, com aproximadamente 1.300 falas diretas (e outras tantas indiretas), é uma encenação do discurso da jagunçagem, especialmente no episódio situado no meio: o julgamento de Zé Bebelo na Fazenda Sempre-Verde ${ }^{10}$. Trata-se de uma cena-chave que nos permite observar como o sistema jagunço fala de si mesmo. Zé Bebelo, Joca Ramiro, Ricardão, Hermógenes e os demais chefes com seus comandados são figuras cuja existência está fundamentada no discurso da jagunçagem - entendendo-se "discurso", no sentido de Michel Foucault, como a representação verbal de uma instituição -, que existe também fora do romance e condiciona a fala de todos os seus integrantes, sejam eles reais ou ficcionais.

Assim como o interlocutor urbano, nós leitores entramos em contato com o universo da jagunçagem através da mediação de Riobaldo. Acompanhando a sua perspectiva de agente participante, nos inteiramos dos discursos dos jagunços. Riobaldo observa as falas, principalmente dos chefes, comenta-as criticamente e até intervém no debate. Enquanto jagunço-letrado, o narrador rosiano pertence simultaneamente ao universo da violência (o bruto sertão) e da urbanidade (o espaço da norma culta e de uma educação superior). Ele realiza assim um trabalho de mediação entre duas esferas culturais muito diferentes, e ao mesmo tempo é capaz de distanciar-se criticamente de cada uma delas.

Vejamos algumas características da formação de Riobaldo enquanto jagunço letrado e da linhagem dentro da qual ele se situa. Graças às providências de seu pai, o latifundiário e coronel Selorico Mendes, Riobaldo recebeu desde cedo uma dupla formação: a de um guerreiro letrado. Essa linhagem começou na Antiguidade com uma figura como Júlio César e teve continuidade na Era Moderna em Cervantes, no Dom Quixote (cap. XXXVIII), com o "discurso sobre as Armas e as Letras". Trata-se de uma codificação das relações entre os dois estamentos que compunham a elite: a chevalerie e a clergie. A combinação dessa dupla competência caracteriza a "formação do patronato político brasileiro", como mostrou Raymundo Faoro em seu estudo $0 s$ donos do poder (1958) ${ }^{11}$. Trata-se de uma aliança entre o poder patrimonial, fundamentado na propriedade particular (os latifundiários-coronéis com suas milícias), e o estamento, isto é, os letrados (peritos em leis), que formam a corporação dos altos funcionários do Estado.

10 ROSA, João Guimarães. Grande sertão: veredas. 5. ed. Rio de Janeiro: José Olympio, 1967. p. 196-217. Doravante GS:V.

11 FAOR0, Raymundo. Os donos do poder: formação do patronato político brasileiro. 11. ed. São Paulo: Editora Globo, 1997. 2 v. 
Como Riobaldo usa sua competência nas letras, iniciada com a aprendizagem da "gramática" e o "estudo pátrio"? ${ }^{12}$ Modestamente, ele se apresenta como leitor de almanaques, vidas de santo e romances ${ }^{13}$. Mas não nos enganemos: efetivamente, ele emprega seu talento para conhecer o funcionamento da máquina do poder. "Estudei foi os chefes" ${ }^{14}$, declara ele por ocasião do julgamento de Zé Bebelo, e é isso que nos leva a conhecer a retórica do sistema jagunço.

\section{4. "Condena de absolvido" ou: A retórica dos chefes}

À primeira vista, Grande sertão: veredas pode parecer uma epopéia da jagunçagem. Esse ângulo de leitura impregna fortemente a tradução alemã, a qual, significativamente, manteve apenas a primeira parte do título, deixando de lado o contraponto das "veredas". Com efeito, uma parte da narração rosiana apoia-se nas tradicionais histórias apologéticas dos "fazendeiros graúdos mandadores", os coronéis. "A guerra foi grande [...] Vão fazer cantigas, relatando as tantas façanhas"15. Estas palavras de Riobaldo fazem eco às histórias que ele ouviu na adolescência narradas pelo seu pai. É uma visão romântica e idealizada da jagunçagem. Por outro lado, existe também um distanciamento que expõe o que há de mitificador nesse tipo de discurso: "De ouvir meu padrinho contar aquilo [...] começava a dar em mim um enjôo. Parecia que ele queria emprestar a si as façanhas dos jagunços".

As idealizações de figuras como Medeiro Vaz, seu Joãozinho Bem-Bem e Joca Ramiro fazem parte de um imaginário coletivo, alimentado pela mitologização. Zé Bebelo, por exemplo, ao assumir a chefia do bando de jagunços, estufa o peito e atribui a si mesmo as qualidades de todos os precursores: "Meu nome d'ora por diante vai ser ah-oh-ah o de Zé Bebelo Vaz Ramiro!" Através do irreverente "ah-oh-ah" o narrador nos sinaliza que está desconstruindo o discurso mitologizante.

Também o retrato de Medeiro Vaz oscila entre a mitificação e a desconstrução do mito. Ele é introduzido como um revoltado contra a situação de "guerras e desmandos de jagunços".

12 GS:V, p. 14.

$13 G S: V$, p. 14, 287.

14 GS:V, p. 199.

15 GS:V, p. 209. 
Como um herói, ele despoja-se de todos seus bens, a fim de sair pelo mundo, no comando de uma turma de "gente corajada", "para impor a justiça”. Mas como se manifesta essa justiça na prática? Quando o narrador lembra o caso do homem que se enforcou por medo do bando dos medeiro-vazes e a disposição de Medeiro Vaz de "dar firme ordem para se matar uma a uma as mil pessoas", desaparece a imagem do grande libertador social, e fica apenas o perfil de um justiceiro.

Uma desconstrução semelhante se dá com o chefe Joca Ramiro, representante supremo da "justiça e alta política"16. Conforme os padrões dos romances de cavalaria, sua figura é estilizada como "par-de-França, capaz de tomar conta deste sertão nosso, mandando por lei, de sobregoverno". Quando esse chefe recorre às armas, é "só em favor de amigos perseguidos; e sempre conservava seus bons haveres". 0 que intriga o narrador, no entanto, é a relação entre essa esfera da "alta política" e o mundo do crime: "Por que era que Joca Ramiro" - pergunta-se Riobaldo - "sendo chefe tão subido, de nobres costumes, consentia em ter como seu alferes um sujeito feito esse Hermógenes, remarcado no mal?"17

0 contraponto à idealização e mitificação é a negativização e mesmo demonização de outros personagens. Ricardão é apresentado como "bruto comercial"18, e o Hermógenes como "monstro", "homem que tirava seu prazer do medo dos outros, dos sofrimentos dos outros"19. Sem dúvida, o dinheiro e o medo sempre foram fatores de peso na vida política. Como observa Riobaldo, é o "medo, que todos acabavam tendo do Hermógenes" 20 que cria a imagem coletiva do homem "pactário", que suscita entre os dominados uma sensação de impotência e uma atitude de submissa admiração.

Com a introdução da figura do latifundiário seô Habão, as idealizações e demonizações da jagunçagem cedem lugar a uma visão prosaica. Esse representante do poder patrimonial - "fazendeiro-mór”, "sujeito da terra definitivo”, com a cabeça voltada para o agro-negócio - não se impressiona com as façanhas narradas por Zé Bebelo e seu bando; para ele, os jagunços "não

$16 G S: V$, p. 37.

17 GS:V, p. 132.

18 GS:V, p. 138.

19 GS:V, p. 138-9.

20 GS:V, p. 309. 
passa[m] de ser home[ns] muito provisório[s]". Assim, as figuras prosaicas do romance - além de seô Habão, também seo Ornelas, Ricardão e Zé Bebelo - proporcionam uma visão não-camuflada das estruturas de poder. Com eles, a jagunçagem aparece sob uma luz mais objetiva.

"Era rico, dono de muitas posses em terras, e se arranchava passando bem em casas de grandes fazendeiros e políticos, deles recebia dinheiro de munição e paga" ${ }^{21}$. Esse retrato poderia ser o de Ricardão, que era "rico, dono de fazendas" e "somente vivia pensando em lucros, querendo dinheiro e ajuntando" - mas é o de Joca Ramiro, visto com os olhos do jagunço Antenor. No julgamento de Zé Bebelo, o narrador chega a "reconhecer a verdade d[as] palavras" proferidas por Ricardão, que relembra as mortes, os sofrimentos e os prejuízos causados pelo réu, e a responsabilidade de Joca Ramiro e seus aliados para com os fazendeiros que os financiam. Focalizando assim a jagunçagem de vários ângulos e revelando os interesses econômicos e políticos que estão em jogo, o romance acaba evidenciando o funcionamento do sistema.

0 episódio central da Fazenda Sempre-Verde visa muito além da pessoa empírica de Zé Bebelo. 0 julgamento do caçador de jagunços pelo bando de "jagunços civilizados"22 é uma grande auto-encenação do sistema jagunço. 0 chefes alimentam em seus subordinados uma série de ilusões: de que a vitória sobre o adversário significaria o fim da guerra; que a guerra dos sertanejos seria uma forma de rebeldia contra o Governo repressor situado na capital do Estado; e que eles, os chefes, se pautariam democraticamente pelo julgamento de seus subordinados: "Que tenha algum dos meus filhos com necessidade de palavra para defesa ou acusação, que pode depor!” Nesses termos, Joca Ramiro procura animar seus "cabras valentes" a falar.

Na verdade, o que se discute na Fazenda Sempre-Verde é a instituição representada alegoricamente pelo nome do réu: "Bebelo" ou "Rebêlo", de re-bellum - aquele que sempre volta a praticar a guerra ${ }^{23}$. A guerra permanente é parte constitutiva do sistema jagunço, e o que ocorre ali é um arranjo muito pouco civilizado entre as forças da oposição (Joca Ramiro) e o candidato a representante do governo (Zé Bebelo), no sentido de legitimar

21 GS:V, p. 137.

22 GS:V, p. 212.

23 Cf. ROSENFIELD, Kathrin. Os descaminhos do demo: tradição e ruptura em Grande Sertão: Veredas. Rio de Janeiro: Imago; São Paulo: Edusp, 1993. 
a guerra e ratificar o sistema vigente, que funciona às custas da mão-de-obra e da população pobre do sertão. Esse acordo é sintetizado por Riobaldo com a fórmula de dar ao réu "condena de absolvido" 24 .

Essa artimanha persuasiva - que, num nível metanarrativo, é uma maneira irônica de nomear a impunidade - encontra uma réplica à altura nas palavras toscas, porém lúcidas, de um tal de Gú. Esse raso jagunço observa que o acordo serve não tanto para quem é "braço d'armas", mas sobretudo para os chefes:

[...] se alguma outra ocasião, algum chefe nosso cair prêso em mão de tenente de meganhas - então também hão de ser tratados com maior compostura, sem sofrer vergonha e maldades... A guerra fica sendo de bem-criação, bom estatuto... ${ }^{25}$

\section{Como o sistema jagunço se reproduz}

Riobaldo, longe de ter acabado com a jagunçagem, como afirma, é um eloqüente exemplo de como o sistema jagunço se reproduz. Ao comentar críticamente as falas durante o julgamento de Zé Bebelo, ele não está no papel de um observador neutro ou desinteressado; é um aprendiz que se prepara para um dia também ocupar uma posição de chefia. Através da trajetória do protagonista, o romance mostra como o sistema jagunço se reproduz e se regenera com a incorporação de novos elementos. A aprendizagem de Riobaldo sobre o funcionamento das artimanhas e da retórica do poder se dá, antes de mais nada, através do convívio com Zé Bebelo.

Essa aprendizagem começou quando Riobaldo exercia o duplo papel de professor e secretário de Zé Bebelo. Com a iniciativa de Zé Bebelo de contratá-lo como professor particular, "para o ensino de todas as matérias", é introduzida no universo do coronelismo tradiconal a figura do letrado.

No episódio do julgamento de Zé Bebelo, a fala de Riobaldo sobressai entre todas as demais pela qualidade oratória; suas opiniões "matar é vergonha" e "absolver é fama de glória” encontram ampla repercussão entre os ouvintes. A mesma habilidade manifestada por Riobaldo em suas falas pode ser observada também na expressão escrita: nos bilhetes que ele redige para as autoridades,

24 GS:V, p. 209.

25 GS:V, p. 207. 
na função de "amanuense", na Fazenda dos Tucanos ${ }^{26}$. No momento em que Zé Bebelo lhe ordena "larga o rifle [...] Escreve...", flagramos um instantâneo emblemático: o tópos das Armas e das Letras, ou seja, o letrado a serviço do poder.

No entanto, a meta do nosso protagonista é aprender com os chefes ${ }^{27}$. E, com efeito, a partir da Fazenda dos Tucanos inicia-se uma mudança na relação entre o chefe e o aprendiz. Suspeitando Zé Bebelo de traição, Riobaldo começa a elaborar mentalmente a idéia da tomada do poder: "[Zé Bebelo] fizesse feição de trair, eu efetuava. [...] Daí eu tomava o comandamento" ${ }^{28}$. Note-se o significado emblemático do lugar. É nessa fazenda, caracterizada pelo narrador como um conjunto formado pelas "senzalas" e a "casa grande" ${ }^{29}$, que se prenuncia a passagem de Riobaldo da condição de subalterno, quase escravo (pela condição social de sua mãe), para o status de senhor.

Conforme os ensinamentos de Maquiavel, a dissimulação é própria do discurso dos soberanos ${ }^{30}$. Segundo um teórico barroco: "Dissimulamos o que somos, simulamos o que não somos". Em Grande sertão: veredas, o discípulo acaba superando o mestre. A ascensão de Riobaldo ao poder é preparada por um discurso duplo. Na Fazenda dos Tucanos, ele protestou diante de Zé Bebelo em nome de "nós, pobres jagunços" ${ }^{\text {". Mas nas }}$ terras do fazendeiro seô Habão, que cobiça os jagunços como enxadeiros, Riobaldo resolve mudar de discurso e identidade: "O senhor conhece meu pai, fazendeiro Senhor Coronel Selorico Mendes [...]?!" 32 Nesta hora decisiva, Riobaldo renega sua condição de pobre e apresenta-se como filho de coronel. 0 aspirante a chefe reproduz o molde da traição. Está pronto para fazer o pacto com o Diabo, que será o meio para ele passar de raso jagunço a chefe de jagunços, ou seja: fazer um "trato de iguais com iguais”, em que ele será a parte que dá as ordens.

26 GS:V, p. 250.

27 GS:V, p. 199.

28 GS:V, p. 253.

29 GS:V, p. 245, 267.

30 MAQUIAVEL, Niccolò. Il Príncipe. Org. por Giuseppe Lisio. Florença: G. C. Sansioni, 1938.

31 GS:V, p. 254.

32 GS:V, p. 315. 
Tudo isso demonstra que Riobaldo assimilou perfeitamente as lições de quem o iniciou na arte de lutar com palavras. Desde as ordens e os decretos proferidos pelo chefe, passando por discursos de candidatura, de posse e de julgamento, até as artimanhas da demagogia, das declarações engambeladoras e dos lances retóricos oportunistas - quantos gêneros e subgêneros da camaralística! Quando situamos Riobaldo dentro da tradição das Armas e das Letras, não podemos abstrair o fato de ele ser a criação de um funcionário do alto escalão do Governo. Guimarães Rosa foi secretário do Ministério das Relações Exteriores, chefe de divisão, cônsul e embaixador, e conhecia perfeitamente a máquina do poder e da retórica. Certamente várias de suas experiências e observações entraram, de forma elaborada, na construção do romance.

Uma vez instituído como chefe, Riobaldo legitima a guerra com a promessa de trazer "glória e justiça", de "impor paz inteira neste sertão" e de "obrar vingança pela morte atraiçoada de Joca Ramiro". Ao mesmo tempo, apresenta a jagunçagem como instituição por excelência para resolver os problemas sociais. "Eu pretendia retirar aqueles, todos, destorcidos de suas misérias" - justifica Riobaldo o aliciamento da mão-de-obra "à mansa força". Na prática, seus grandiloqüentes programas são desmentidos pelo fato de seu bando ir "extorquindo vantagens de dinheiro" por toda a parte - eis o que ele define como o "sistema jagunço" 33 .

Colhendo e montando os fragmentos do discurso do poder, esparsos pelas 500 páginas do romance, as dissimulações e as revelações, o leitor acaba obtendo uma imagem da estrutura política e social vigente. A visão crítica com que o personagem-narrador nos faz ver as artimanhas retóricas dos chefes de jagunços acaba se voltando contra o próprio Riobaldo, a partir do momento em que ele começa a exercer o comando. A retórica da simulação e da dissimulação que ele nos ensinou a observar em Zé Bebelo, nós a identificamos em suas próprias declarações: "Haviam de vir, junto, à mansa força", comenta o chefe Riobaldo sobre o aliciamento dos moradores do Sucruiú pelo seu bando de jagunços. A essa coerção ele atribui cinicamente o sentido de uma ação social: "Isso era perversidades? Mais longe de mim - eu pretendia era retirar aqueles, todos, destorcidos de suas misérias" ${ }^{34}$.

0 chefe Riobaldo usa aqui uma retórica de simulação, que faz de conta que o sistema jagunço é um meio eficiente 
para resolver os problemas sociais. Na verdade, os chefes aproveitam-se da mão-de-obra dos sem-posse para tratarem de seus interesses particulares, que são dissimulados. 0 sistema jagunço serve, portanto, para encobrir os problemas sociais: "Quando se jornadeia de jagunço [...] não se nota tanto: o estatuto de misérias e enfermidades"; a atividade guerreira dissipa os problemas: "Guerra diverte - o demo acha" ${ }^{35}$. Riobaldo se vale da miséria geral para aliciar mão-de-obra para sua empresa. 0 recrutamento compulsório dos homens do Sucruiú e do Pubo é combinado com uma retórica que engana o povo.

Vamos sair pelo mundo, tomando dinheiro dos que têm, e objetos e as vantagens, de toda valia... E só vamos sossegar quando cada um já estiver farto, e já tiver recebido umas duas ou três mulheres, moças sacudidas, p'ra o renovame de sua cama ou rede! ${ }^{36}$

Esta fala demagógica é em nada diferente do apelo para roubos e saques feito pelo Hermógenes. Em ambos os casos, o patrão remunera os serviços prestados por meio de uma empresa criminosa.

A guerra acabou sendo um bom negócio para o chefe Riobaldo, embora pelo preço da perda irreparável de Diadorim. Com a vitória sobre o bando do Hermógenes, na batalha sangrenta do Paredão, Riobaldo ganha uma fama à qual o seu mentor Zé Bebelo sempre aspirava: de ter "limpado estes gerais da jagunçagem" ${ }^{37}$. A isso juntam-se amplas propriedades de terras, através do casamento com Otacília e do testamento deixado para ele por Selorico Mendes. Riobaldo torna-se, assim, um integrante da classe dos latifundiários, ao lado dos seô Habão, seo Ornelas, Zé Bebelo, e tantos, tantos. Como dono do poder, o narrador de Grande sertão: veredas reproduz os padrões de fala e comportamento de sua classe.

"Queria ser rico em paz: para isso guerreava" - até que ponto esta caracterização do personagem Ricardão não se aplicaria também ao "herói" Riobaldo, que termina sua carreira de empresário e caçador de jagunços como membro da classe dominante? Riobaldo deixa claro que, como dono de amplas propriedades, muito bem protegidas pela sua "gente" (isto é: pelos seus

35 GS:V, p. 48.

36 GS:V, p. 337.

37 GS:V, p. 456. 
jagunços), não vai tolerar nenhuma subversão da ordem estabelecida: "Chegassem viessem aqui com guerra em mim, com más partes, com outras leis, ou com sobejos olhares, e eu ainda sorteio de acender esta zona [...]!"38 A condição do protagonista-narrador como um dos porta-vozes do sistema jagunço marca, portanto, decisivamente o modo de narrar em Grande sertão: veredas.

\section{Credibilidade ou construção da credibilidade? Um narrador pactário}

Com isso, coloca-se a questão da confiabilidade do narrador de Grande sertão: veredas. Em que medida podemos acreditar num narrador que, em sua condição de dono do poder, recorre constantemente a uma retórica da simulação e dissimulação? Mais ainda: uma vez que tudo, nesse romance, é mediado por um personagem que fez um trato com o "Pai da Mentira"39, qual é o grau de verdade de suas falas?

0 relato de Riobaldo situa-se dentro dos moldes da retórica clássica, na medida em que a narratio é uma das partes constitutivas do discurso diante do tribunal. É a fala de um dono do poder diante de uma instância de julgamento representada por um doutor da cidade e, virtualmente, por toda uma platéia de letrados. 0 objetivo de Riobaldo é ser absolvido no final, tanto pelo interlocutor quanto pelo leitor. Motivado pela consciência de culpa do dono do poder que passou por cima dos que eram outrora seus iguais e agora são seus servos, o seu discurso é estruturado como uma auto-acusação - mas a qualquer momento pode transformar-se num discurso de legitimação. Com isso, entrevê-se alegoricamente, através da história dessa vida particular, a história de toda uma classe.

A estratégia discursiva fundamental de Riobaldo consiste em constituir-se diante do interlocutor como um narrador digno de confiança. Como discernir até que ponto se trata de um narrador confiável ou de uma mera encenação da credibilidade? Para ver mais claro nessa narração de Riobaldo, comandada por duas instâncias opostas - a verdade e a simulação da verdade -, lembremos alguns elementos da teoria da retórica. Por um lado, temos a arte da persuasão, em que o primordial é a construção da credibilidade; essa retórica é representada pelo discurso de Riobaldo como dono do poder. É um tipo de retórica que privilegia a construção da credibilidade em detrimento da busca da

38 GS:V, p. 21-2.

$39 G S: V$, p. 317. 
verdade. Quintiliano define essa retórica como arte da persuasão (vis persuadendi) e mesmo como arte de enganar (ars fallendi) ${ }^{40}$. Dentro dessa tradição, Maquiavel explica detalhadamente "como os príncipes devem manter a sua credibilidade”. 0 príncipe precisa aparentar ter estas cinco qualidades: piedade, fé, honestidade (integrità), humanidade e religião.

Por outro lado, temos a busca da verdade e da justiça, que caracteriza a ética do homem justo e bom; é a retórica como "ciência de falar bem", no sentido ético e estético, a bene dicendi scientia, como a denomina Quintiliano. As duas modalidades de retórica são relevantes também para a prática poética e a teoria literária, na medida em que os estudiosos (notadamente Wayne Booth, The rhetoric of fiction, 1961) pesquisam a diferença entre narradores “confiáveis" e "não-confiáveis". Simultaneamente nãoconfiável e confiável, o narrador Riobaldo lança mão de ambas as retóricas. $\mathrm{E}$ às vezes, sua credibilidade efetiva resulta dialeticamente de um malogro da credibilidade que ele pretende construir.

Uma das estratégias retóricas mais trabalhadas por Riobaldo consiste em apresentar-se diante do interlocutor como um homem de fé:

Muita religião, seu moço! Eu cá, não perco ocasião de religião. Aproveito de todas. [...] Rezo cristão, católico [...] e aceito as preces de compadre meu Quelemém, doutrina dele, de Cardéque. Mas quando posso, vou no Mindubim, onde um Matias é crente, metodista: a gente se acusa de pecador, lê alto a Bíblia, e ora, cantando hinos belos deles. [...] Eu queria rezar - o tempo todo. ${ }^{41}$

Com essa fala, Riobaldo parece imitar o exemplo de Zé Bebelo, o qual, sempre que possível (e como que seguindo uma recomendação de Maquiavel), usa referências religiosas para fundamentar sua autoridade. Como no julgamento dos irmãos parricidas, quando invoca a "Santíssima Virgem": "Zé Bebelo se entesou sério, em pufo, empolo [...], eu prestes vi que ele estava se rindo por de dentro"42. Através de seu comentário, o narrador deixa claro que se trata de uma religiosidade construida.

Num dado momento, Riobaldo procura aproveitar as lições do seu mentor em causa própria. No episódio em que os cinco

40 QUINTILIANO, Marcus Fabius. Institutio oratoria: Ausbildung des Redners.

Org. e trad. de Helmut Rahn. 2. ed . bilíngüe latim-alemão. Darmstadt:

Wissenschaftliche Buchgesellschaft, 1988. 2 v.

41 GS:V, p. 15.

$42 G S: V$, p. 60. 
urucuianos lhe anunciam que vão embora, o chefe Riobaldo tenta demovê-los com uma fala que é uma adaptação dos estratagemas retóricos de Zé Bebelo: "Ah, então, para avaliar em prova a dúvida dêles, tive um recurso. A manha, como de inesperadamente de repente eu muito disse: - Louvado seja Nosso Senhor Jesus Cristo!” Desta vez, porém, a fórmula falha. Pelo "tom da voz" de Riobaldo, o cabecilha dos urucuianos percebe o estratagema e o narrador se vê obrigado a admitir: "no afã de querer pronunciar sincero demais o santíssimo nome, eu mesmo tinha desarranjado fala - essas nervosias..." ${ }^{n 3}$

Essa autocrítica é um indício de que existem frestas no discurso de Riobaldo como dono do poder. Se, num primeiro nível, a feitura dos discursos de Zé Bebelo se torna transparente através dos comentários de Riobaldo, num segundo nível, isso ocorre também com a retórica do próprio protagonista-narrador. 0 fato de ele tornar transparente a sua construção da credibilidade - sua arte da persuasão ou arte de enganar - reverte dialeticamente numa nova qualidade: num ganho de credibilidade junto ao ouvinte/leitor, pois nesse momento ele se orienta pela ética do homem justo e bom, por uma retórica e poética enquanto ciência de falar bem. Tais montagens contrastivas, operadas pelo próprio escritor, configuram uma poética metanarrativa.

\section{A meta narrativa: Guimarães Rosa como preceptor luciférico do Brasil}

Por que a opção de Guimarães Rosa por um narrador pactário? Em vez de proferir conceitos de moral, como tantos preceptores convencionais, o autor de Grande sertão: veredas criou um personagem-narrador que pesquisa os fenômenos da violência e do crime dentro de si. Em vários momentos, Riobaldo registra como surge dentro dele o impulso para a violência, espontaneamente e com a perspectiva de plena impunidade. Como no caso da mocinha, neta de seo Ornelas, cuja "boniteza" ele sente "em suas carnes" e que ele quer "agarra[r] nos [seus] braços", como "uma quanta-coisa primorosa que se esperneia..." Ou o caso de um transeunte, nhô Constâncio Alves que, de repente, provoca em Riobaldo "o doido afã de matar aquele homem [...] matar, matar assassinado, por má lei" ${ }^{\text {45 }}$. Na tentativa de

$43 G S: V$, p. 378.

$44 G S: V$, p. 345.

45 GS:V, p. 355. 
explicar esses impulsos, Riobaldo observa: "quem mandava em mim já eram os meus avessos", "o demo então era eu mesmo?" Não seriam essas tentações que ele experimenta uma prova de que o demônio é uma parte constitutiva do ser humano?

"Sertão: é dentro da gente" $"$. A auto-análise radical de sua própria pessoa leva Riobaldo a estender o conhecimento do sertão como arqui-paisagem da violência em forma de um retrato da sociedade brasileira como um todo. Jagunço letrado, narrador pactário e também professor, ele mergulha a fundo nas manifestações do sistema jagunço, sobretudo em seu discurso que, freqüentemente, se confunde com o discurso oficial do poder, com sua retórica da simulação e da dissimulação. 0 insight dentro da máquina do poder e do seu funcionamento é proporcionado notadamente pelo modo como Riobaldo desconstrói o discurso de Zé Bebelo. No papel de "o Deputado"48, este personagem representa emblematicamente o poder legislativo, instituidor das leis, ou seja, o poder fundador do Estado. A concentração de tantos comentários do narrador rosiano sobre o personagem, um permanente aspirante ao Governo, é um forte indício de que o autor desse retrato do Brasil que é Grande sertão: veredas visava, através do sistema jagunço, o sistema político como um todo.

Aqui poderíamos pôr um ponto final. Mas faltaria alguma coisa essencial se omitíssemos o fato de que naquele fim de tarde do dia 15 de maio de 2006, quando acabamos de expor esta comunicação sobre o Brasil jagunço, no campus da Universidade de São Paulo, o diretor da Faculdade de Filosofia, Letras e Ciências Humanas anunciou a suspensão de todas as atividades diante do fato de que naquele dia a população de São Paulo sofreu a ameaça do crime organizado, de bandidos do PCC (Primeiro Comando da Capital), que desafiavam abertamente o poder público representado pelo Governo. Ou seja, a paisagem da violência, no Brasil, não é mais um longínquo sertão lá no "alto brabo norte" de Minas Gerais; nestas últimas cinco décadas, da publicação de Grande sertão: veredas para cá, o sertão avançou para o coração das nossas metrópoles, inclusive para aquela que costuma ser considerada a mais avançada: a cidade de São Paulo.

Por força de acontecimentos assim, o banditismo e o crime deveriam fazer parte, desde já, dos manuais de História

46 GS:V, p. 355-6.

47 GS:V, p. 235.

48 GS:V, p. 101. 
do Brasil. E, sem dúvida, seus autores poderão aprender muito com esse preceptor luciférico que é Guimarães Rosa. Na figura de Riobaldo ele criou um mediador dialético que traduz a autoreflexão do letrado, a complexidade da posição do intelectual, entre os donos do poder e as classes subalternas, contra o pano de fundo dos enormes problemas sociais e do crime. Nesse contexto, o que nos ajuda a esclarecer a opção de Guimarães Rosa por um narrador pactário é a teoria da "literatura de dois gumes", formulada em 1968 por Antonio Candido nestes termos:

Na sociedade duramente estratificada, submetida à brutalidade de uma dominação baseada na escravidão, se de um lado os escritores e intelectuais reforçaram os valores impostos, puderam muitas vezes, de outro, usar a ambigüidade do seu instrumento e de sua posição para fazer o que é possível nesses casos: dar a sua voz aos que não poderiam nem saberiam falar em tais niveis de expressão. ${ }^{49}$

A situação assim descrita caracteriza perfeitamente o caso de Riobaldo e do autor de Grande sertão: veredas. 0 narrador - e, num outro nível, o escritor - expressa o ponto de vista de um dono do poder, ao mesmo tempo em que dá voz às pessoas do povo que não dispõem de recursos equivalentes de expressão. É uma estratégia dupla, paradoxal e contraditória, um sistema complexo de mediação, que precisa ser repensado e reatualizado à luz das transformações históricas das quais somos testemunhas.

Recebido em: Dez. 2006 Aprovado em: Jan. 2007

49 CANDID0, A. Literatura de dois gumes. In: A educação pela noite e outros ensaios. São Paulo: Ática, 1987. p. 163-180. 